\title{
PENGEMBANGAN PRODUKSI PERTANIAN LAHAN KERING DENGAN SISTEM LOW EXTERNAL INPUT SUSTAINABLE AGRICULTURE (LEISA) DI DESA CIGADOG, DAN MANDALAGIRI KECAMATAN, LEUWISARI KABUPATEN TASIKMALAYA
}

\author{
Nuraini, A., Yuwariah, Y. dan Rochayat, Y. \\ Fakultas Pertanian Universitas Padjadjaran \\ E-mail: yuyun yuwariahas@unpad.ac.id
}

\begin{abstract}
ABSTRAK
Pengabdian kepada masyarakat program KKNM PPMD Integratif Periode Januari-April 2014 dengan judul "Pengembangan Produksi Pertanian Lahan Kering dengan Sistem Low External Input Sustainable Agriculture (LEISA) di Desa Cigadog dan Mandalagiri Kecamatan Leuwisari, Kabupaten Tasikmalaya" telah dilaksanakan dengan tujuan meningkatkan pengetahuan dan keterampilan petani dalam mengembangkan pertanian di lahan kering dengan sistem LEISA. Hasil evaluasi menunjukkan bahwa secara umum, program penyuluhan telah berhasil karena adanya peningkatan sasaran antara strategis dari tidak tahu menjadi tahu dan terampil, beberapa sasaran antara strategis yang diberi penyuluhan menyatakan ketertarikan untuk menggunakan sistem LEISA dengan memenfaatkan potensi local untuk produksi tanaman yang mereka usahakan khususnya di lahan kering, dan akan menularkan ilmunya ke petani lainnya. Salah satu masalah yang masih menjadi kendala dalam mendukung untuk merealisasikan potensi tersebut adalah terbatasnya petugas penyuluh pertanian yang harus melayani daerah yang cukup luas sehingga pembinaan terhadap petani kurang maksimal
\end{abstract}

Kata kunci:

\begin{abstract}
Community service program PPMD Integrative KKNM period from January to April 2014, with the title “ Development of Dryland Agriculture Production Systems with Low External Input Sustainable Agriculture ( LEISA ) Cigadog village and sub-district Mandalagiri Leuwisari Tasikmalaya district " has been implemented with the aim of improving the knowledge and skills of farmers in develop agriculture in dryland with LEISA systems. The results showed that in general, counseling programs have been successful because of the increase between the strategic objectives of not knowing to knowing and skilled, some of the strategic objectives that were given counseling expressed interest in using the system memenfaatkan LEISA the local potential for the production of plants that they have earned, especially in dry land, and will pass on their knowledge to other farmers. One of the problems is still a constraint in support to realize this potential is limited agricultural extension officers to serve a wide area, thus providing guidance to farmers less than the maximum
\end{abstract}

Key words:

\section{PENDAHULUAN}

Desa Cigadog dan Mandalagiri merupakan desa yang terletak di Kecamatan Leuwisari Kabupaten Tasikmalaya. Kecamatan Leuwisari memiliki data demografi wilayah sebagai berikut: secara geografis luas wilayahnya $5.416,55$ ha, yang terdiri atas perukiman 210,45 ha, pertanian $2.298,00$ ha, perkebunan 2,50 ha, kolam 2.083,80 ha, alang-alang 2,50 ha, ladang 810,00 ha, dan lain-lain 9,30 ha. Batas administratif Kecamatan Leuwisari sebelah utara adalah Gunung Galunggung, sebelah selatan adalah Kecamatan Singaparna, sebelah timur adalah Kecamatan Padakembang, dan sebelah barat adalah Kecamatan Sariwangi.

Prasarana perhubungan di Kecamatan Leuwisari adalah: jalan kabupaten $12 \mathrm{~km}$, kantor 27 gedung, GOR 4, lapangan 11. Prasarana pendidikan yang ada di Kecamatan Leuwisari adalah: TK 3 buah, TPA 24, Madrasah 39, SD 20, MI 3, SMP 1, MTs 2, Panti Sosial 1, dan Balai Pengobatan 1.

Desa Cigadog terletak di sekitar hutan dengan kontur tanah berbukit dan bergelombang, luas wilayahnya sekitar 189,5 ha. Di sebelahutara Desa Cigadog berbatasan dengan hutan lindung, di sebelah selatan dengan Desa Jayamukti, di sebelah timur dengan Desa Mandalagiri, dan di sebelah barat dengan Desa Linggamulya.

Desa Cigadog didominasi oleh lahan pertanian sehingga mata pencaharian sebagian besar penduduknya adalah petani dan buruh tani. Jenis tanaman yang sering ditanam adalah padi, kacang-kacangan, cabai, dan sayur-sayuran lainnya. Komoditas pertanian tersebut mempunyai nilai jual yang tinggi. Selain itu, pekarangan yang dimiliki oleh masyarakat Cigadog juga berperan penting dalam pemenuhan kebutuhan harian. Pekarangan biasanya ditanami dengan tanaman tahunan atau semusim; yang memiliki potensi ekonomi yang cukup tinggi antara lain adalah kakao dan manggis.

Desa Mandalagiri berada di kaki gunung Galunggung yang berbatasan dengan Desa Cigadog dan Jayamukti di sebelah barat, Desa Padakembang dan Desa Cisaruni di sebelah timur, Desa Ciawang di selatan, dan Gunung Galunggung di sebelah utara. Lokasi dusun-dusunnya dimulai dari utara ke selatan ialah Dusun Sukatani, DusunTaruju, Dusun Paniis, dan Dusun Cijambe.

Luas wilayah Desa Mandalagiri berkisar 315 hektar. Lahan yang ada di Desa Mandalagiri, baik yang di hutan pegunungan maupun di kaki gunung Galunggung, dimanfaatkan oleh warga setempat sebagai lahan pendapatan. Hutan yang ada di desa itu termasuk hutan lindung dengan luas 90 hektar. Di Dusun Sukatani sebagian besar lahan digunakan untuk berkebun, bertani, dan beternak. Para warga akan menggunakan lahan di sekita rumah dan di daerah pegunungan. Hasil pertaniannya antara lain berupa buncis, mentimun, kacang panjang, dan bawang.

Sebagian besar wilayah Desa Cigadog dan Mandalagiri merupakan lahan kering yang sebagian besarnya merupakan lahan pertanian. Mata pencaharian masyarakat sebagian besar bertani. Komoditas yang 
banyak diusahakan adalah padi yang dibudidayakan pada lahan sawah, sedangkan lahan kering banyak ditanami tanaman pangan, sayuran, dan palawija.

Usaha pertanian pada saat ini telah banyak menggunakan input bahan sintetik, baik pupuk maupun pestisida organik. Salah satu alternatif usaha pertanian yang ramah lingkungan adalah Low External Input Sustainable Agriculture (LEISA). LEISA merupakan suatu acuan pertanian untuk mengoptimalkan pemanfaatan sumberdaya lokal dengan kombinasi komponen usaha tani yang sinergistik serta pemanfaatan input luar sebagai pelengkap untuk meningkatkan efektivitas sumberdaya dan meminimalkan kerusakan lingkungan (Asandhi dll., 2005).

Low External Input Sustainable Agriculture lebih menekankan efisiensi penggunaan faktor prduksi yang ada untuk menciptakan pertanian yang berkelanjutan. Adapun lima prinsip dari pertanian berkelanjutan yaitu kemantapan secara ekologis, keberlanjutan secara ekonomis, adil, manusiawi, dan luwes (Reintjes, 1999).

Untuk meningkatkan produksi pertanian yang berkelanjutan dan ramah lingkungan di Desa Cigadog dan Mandalagiri Kecamatan Leuwisari Kabupaten Tasikmalaya Jawa Barat perlu dilakukan dengan sistem LEISA. Kelompok sasaran dari kegiatan ini adalah kelompok tani, kelompok pemuda, dan kelompok PKK. Kelompok pemuda diharapkan sebagai sarana "transfer of knowledge" agar teknologi itu dimanfaatkan lebih lanjut.

Beberapa prinsip ekologi mendasar dapat dijadikan sebagai acuan di dalam proses pengembangan sistim LEISA. Prinsip-prinsip ekologi dasar pada LEISA dapat dikelompokkan sebagai berikut.

1) Menjamin kondisi tanah yang mendukung bagi pertumbuhan tanaman (dengan mengelola bahan organik dan kehidupan dalam tanah).

2) Mengoptimalkan ketersediaan unsur hara dan menyeimbangkan arus unsur hara (pengikatan nitrogen daur ulang dan pemanfaatan pupuk luar).

3) Mengelola iklim mikro, air, dan pengendalian erosi.

4) Meminimalkan serangan hama dan penyakit melalui cara yang aman.

5) Melengkapi dan memadukan penggunaan sumber daya genetik yang mencakup penggabungan dalam sistim pertanian terpadu dengan tingkat keanekaragaman fungsional yang tinggi.

Bidang KKNM-PPMD yang kami usulkan adalah peningkatan pendapatan petani dan kelestarian lingkungan yang diupayakan melalui pelatihan sistem LEISA dengan penggunaan sumber daya lokal baik benih, pupuk organik, maupun pestisida organik.

\section{BAHAN DAN METODA}

\section{Kerangka Pemecahan Masalah}

Evaluasi dilakukan tiga kali sebagaimana diuraikan berikut ini.

1) Evaluasi awal dilakukan untuk mengetahui posisi pengetahuan petani tentang penggunaan benih bersertifikat.

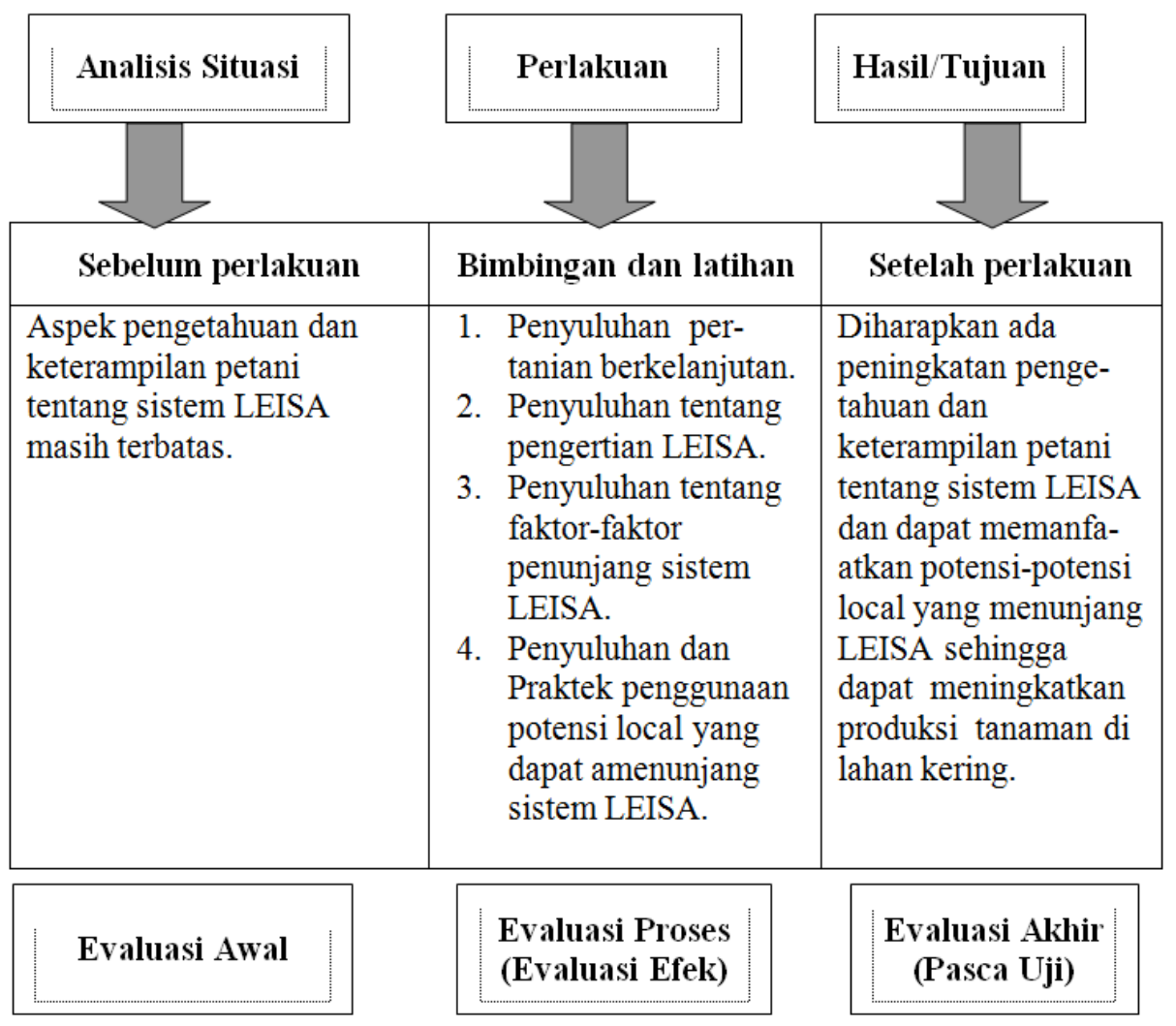

Gambar 1. Kerangka Pemecahan Masalah 
2) Evaluasi proses dilakukan pada saat perlakuan untuk mengetahui kemajuan pengetahuan sasaran.

3) Evaluasi akhir dilakukan untuk mengetahui keberhasilan perlakuan seperti dari tidak tahu menjadi tahu, dari tidak terampil menjadi terampil.

\section{Metode Pelaksanaan}

Khalayak sasaran dalam kegiatan ini adalah para petani tanaman pangan dan sayuran di Desa Cigadog dan Mandalagiri Kecamatan Leuwisari Kabupaten Tasikmalaya dengan pembinaan secara langsung pada petani untuk menggunakan benih bersertifikat serta mampu melakukan produksi, pengolahan, dan penyimpanan benih. Kegiatan dilakukan di Balai Pertemuan Desa dan di lahan percobaan (demplot partisipatif). Kegiatan dilakukan di Balai Pertemuan Desa Cigadog dan di lahan petani (demplot partisipatif). Kegiatan dilakukan selama 4 bulan. berikut.

Kegiatan ini dilakukan dengan cara yang

1. Survei potensi desa

Survei dilakukan untuk mengetahui daerah mana pada desa ini yang mempunyai potensi untuk dilaksanakannya kegiatan ini sehingga dari faktorfaktor yang menunjangnya, kegiatan ini bisa sukses terlaksana.

2. Pengumpulan data

Pengumpulan data dilakukan untuk mendata berapa masyarakat sasaran yang tertarik untuk ikut kegiatan.

3. Penyuluhan dan pelatihan dilaksanakan di balai Desa Cigadog yang dapat menampung orang cukup banyak. Penyuluhan dilakukan menggunakan alat bantu multimedia berupa note book dan infocus.

4. Kegiatan percontohan (demonstrasi plot/demplot partisipatif)

Setelah dilakukan penyuluhan dan pelatihan, kemudian dilakukan kegiatan percontohan di lahan petani setempat penggunaan potensi local untuk meningkatkan pertanian lahan kering dengan sistem LEISA. Pembinaan dilakukan dengan memonitor perkembangan demplot.

5. Pembinaan

Pembinaan lanjutan dilakukan bagi petani meliputi: pembinaan aspek teknik budidaya, dan pemasaran

\section{Kelompok Sasaran}

Khalayak sasaran dalam kegiatan ini adalah para petani lahan kering di Desa Cigadog dan Mandalagiri Kecamatan Leuwisari Kabupaten Tasikmalaya dengan pembinaan secara langsung pada petani untuk menggunakan sistem LEISA. Kegiatan dilakukan di Balai Desa dan di lahan percobaan (demplot partisipatif).

Berdasarkan hasil penyuluhan dan pelatihan akan dilakukan kegiatan percontohan sistem LEISA di lahan kering supaya dihasilkan pertanian yang berkelanjutan.

\section{Partisipasi Masyarakat}

Masyarakat berpartisipasi dari mulai penyuluhan, pembuatan demplot, pemeliharaan tanaman pangan, dan sayuran yang menggunakan benih bermutu. Partisipasi masyarakat diharapkan tidak hanya dalam penyediaan waktu untuk mengikuti penyuluhan tetapi juga penyediaan lahan untuk demplot, tenaga, dan sarana produksi tanaman pangan dan sayuran karena hasilnya akan digunakan oleh petani sendiri.

Keberlanjutan program dilakukan dengan terus mengadakan pembinaan dan pendampingan dalam penerapan sistem LEISA untuk peningkatan produksi pangan palawija dan sayuran di lahan kering dalam rangka menuju desa mandiri pangan.

\section{HASIL DAN PEMBAHASAN}

\section{Hasil yang Dicapai}

Kegiatan pengabdian pada masyarakat di Desa Cigadog dan Mandalagiri dimulai dengan survey potensi desa untuk melihat potensi daerah dan kearifan lokal yang bisa menunjang peningkatan pertanian lahan kering dengan sistem Low External Input Sustainable Agriculture (LEISA). Dari hasil survey dapat disimpulkan bahwa kedua desa mempunyai potensi yang sangat besar untuk pengembangan tanaman di lahan kering dengan tanaman pangan, palawija, dan sayuran.

Berdasarkan hasil survey tersebut kemudian digali permasalahan dari petani, tokoh masyarakat maupun kepala desa. Dari hasil diskusi dengan beberapa petani ini ada beberapa permasalahan yang masih menjadi kendala dalam produksi tanaman di lahan kering, antara lain:

1) faktor alam yaitu: curah hujan yang tidak menentu;

2) penggunaan benih yang seadanya dari pertanaman sebelumnya dan belum menggunakan benih yang bersertifikat

3) teknik budidaya yang masih belum sempurna dan cenderung turun temurun dengan menggunakan pupuk anorganik yang berlebihan yang ternyata tidak semakin meningkatkan hasil, tetapi hasil cenderung turun karena terjadi kerusakan tanah akibat pemupukan anorganik yang berlebihan;

4) serangan hama dan penyakit; dan

5) penanganan pascapanen yang masih sederhana.

Dari hasil diskusi tersebut dapat ditarik kesimpulan bahwa masih ada potensi untuk meningkatkan hasil tanaman di lahan kering di Desa Cigadog dan Mandalagiri dengan sisten LEISA di antaranya dengan penggunaan benih bermutu dan pemanfaatan potensi lokal untuk menunjang sistem LEISA. Di Desa Cigadog dan Mandalagiri banyak terdapat potensi lokal yang dapat dimanfaatkan untuk sistem LEISA, di antaranya banyak peternakan baik itu ayam, kambing, dan sapi yang kotorannya dapat digunakan untuk pupuk organic. Banyak bahan yang dapat dibuat untuk kompos, dan juga banyak potensi untuk pembuatan pestisida nabati. Selain bahanbahan tersebut, pola tanam di lahan kering juga masih belum optimal dan masih dapat ditingkatkan misalnya dengan multiple cropping salah satunya dengan cara tumpang sari. Masalah-masalah itu merupakan topik-topik yang didiskusikan dalam bentuk penyuluhan dan tanya jawab yang diadakan pada pertemuan dengan petani.

Kegiatan penyuluhan di Desa Cigadog dan Mandalagiri dilaksanakan di Balai Desa Cigadog hari Rabu, 22 Januari 2014, pada pukul 13.00 sampai 16.00 WIB. Pelaksanaan kegiatan agak mundur dari jadwal yang sudah ditentukan, penyuluhan baru dimulai pukul 
14.00, karena petani baru usai bekerja dari sawah atau kebun. Penyuluhan dihadiri oleh sekitar 40 orang, peserta kebanyakan dari Desa Cigadog sedangkan perwakilan dari Desa Mandalagiri hanya sekitar 10 . Yang hadir pada penyuluhan merupakan tokoh-tokoh masyarakat tani yang nantinya dapat menjadi agen penerus informasi untuk disebarkan kepada petani lainnya. Jumlah kehadiran peserta penyuluhan yang cukup banyak menunjukkan bahwa antusiasme petani cukup tinggi untuk mendapatkan informasi baru dan juga untuk berbagi pengalaman dalam bertani khususnya tanaman di lahan kering.

Penyuluhan dibuka oleh kepala Desa Cigadog yaitu Bapak Yayat, selanjutnya materi tentang perlunya melaksanakan pertanian berkelanjutan dan sistem LEISA disampaikan oleh ketua Tim pengabdian yaitu Prof. Dr. Ir. Yuyun Yuwariah, M.S.

Penyuluhan dilanjutkan dengan materi tentang faktor-faktor yang dapat menunjang sistem LEISA di antaranya perlunya penggunaan benih unggul bermutu tinggi, pemanfaatan pupuk organik yang ada di daerah setempat, cara pembuatan pupuk organik dengan penggunaan mikroorganisme yang efektif yang dapat mempercepat dan meningkatkan kualitas pupuk organik. Penyuluhan disampaikan oleh Dr. Ir. Anne Nuraini. Penyuluhan disampaikan menggunakan power point/ slide show dan LCD. Penyuluhan dilengkapi dengan alat peraga berupa beberapa jenis benih bersertifikat dengan berbagai kemasan, contoh-contoh pupuk organik baik padat maupun cairan, dan mikroorganisme efektif. Materi ditutup dengan penyampaian informasi bagaimana cara budidaya tanaman pangan dan sayuran yang baik/GAP (Good Agriculture Practices). Materi penyuluhan dapat dilihat pada Tabel 1.

Tabel 1. Materi Penyuluhan

\begin{tabular}{|c|c|c|}
\hline Pertemuan & Materi & Pokok Bahasan \\
\hline 1. & $\begin{array}{l}\text { Pertanian } \\
\text { Berkelanjutan }\end{array}$ & - Pengertian \\
\hline 2. & LEISA & -Prinsip-prinsip LEISA \\
\hline 3. & Pemupukan & $\begin{array}{l}\text {-Kesuburan fisik, kimia dan } \\
\text { biologi } \\
\text {-Pupuk organik : pupuk } \\
\text { kandang, pupuk hayati } \\
\text {-Pupuk anorganik : Urea, } \\
\text { TSP, KCl } \\
\text {-Manfaat unsur hara makro } \\
\text { dan mikro } \\
\text {-Cara pemupukan }\end{array}$ \\
\hline 4. & $\begin{array}{l}\text { Pengendalian } \\
\text { OPT }\end{array}$ & - Pestisida nabati \\
\hline 5 & $\begin{array}{l}\text { Penggunaan } \\
\text { benih yang } \\
\text { bersertifikat }\end{array}$ & $\begin{array}{l}\text { - Kelas benih dan warna label } \\
\text { benih } \\
\text { - Proses Sertifikasi Benih }\end{array}$ \\
\hline 6. & $\begin{array}{l}\text { Penggunaan } \\
\text { potensi } \\
\text { lokal untuk } \\
\text { mendukung } \\
\text { sistem LEISA }\end{array}$ & $\begin{array}{l}\text {-Pupuk organik, penggunaan } \\
\text { mikroorganisme lokal, } \\
\text { pestisida nabati, pola tanam }\end{array}$ \\
\hline
\end{tabular}

Dari diskusi dengan petani terungkap bahwa ada juga petani yang sudah menggunakan benih bermutu tetapi hasilnya masih kurang memuaskan. Hal itu disebabkan oleh faktor cuaca yang saat ini agak sulit diprediksi karena terjadi curah hujan yang sangat tinggi sehingga menyebabkan banyak tanaman sayuran seperti kol, bunga kol, cabe, dan tomat mengalami serangan penyakit meskipun sudah menggunakan benih bermutu. Faktor alam yang sulit dikendalikan dapat diatasi dengan pengaturan pola tanam yang harus disesuaikan dengan curah hujan.

Selain sudah ada beberapa petani yang menggunakan benih bersertifikat, cukup banyak petani yang sudah menggunakan pupuk organik, tetapi mereka belum secara maksimal memanfaatkan potensi lokal untuk pupuk organik. Masih sedikit petani yang sudah tahu penggunaan mikroorganisme yang efektif untuk meningkatkan kualitas pupuk organik. Penggunaan pestisida nabati masih sangat terbatas karena pengetahuan mereka masih terbatas tentang pestisida nabati.

Dari hasil diskusi pada kegiatan penyuluhan ini dapat diketahui bahwa sebenarnya petani sudah banyak yang tahu tentang penggunaan bahan-bahan organik untuk pupuk maupun pestisida, tetapi kebanyakan petani masih enggan menggunakannya karena lebih mudah menggunakan pupuk dan pestisida buatan pabrik karena sangat mudah didapat di kios-kios pertanian dengan dosis yang lebih rendah dari bahan-bahan organik. Namun, dengan penyuluhan bahwa penggunaan bahanbahan anorganik lama-kelamaan akan membahayakan lingkungan baik itu tanah maupun tanamannya itu sendiri dan untuk keberlanjutan pertanaman di lahan kering, akhirnya mereka menyadari bahaya penggunaan bahanbahan anorganik yang berlebihan dan tidak sesuai aturan akan mengganggu pertanian yang berkelanjutan dan para petani mulai sadar bahwa masih banyak potensi lokal yang belum dimanfaatkan secara maksimal.

Dari segi pola tanam, pengetahuan petani masih sangat terbatas mengenai berbagai jenis multiple cropping, tetapi beberapa petani sudah melaksanakan tumpang sari meskipun dengan jenis tanaman yang masih sangat terbatas. Dengan diberikannya penyuluhan tentang beberapa manfaat tentang multiple cropping yang dapat meningkatkan produktivitas pertanian lahan kering, para petani mulai tergerak untuk melakukan beberapa jenis multiple cropping.

Pembuatan demplot, penanaman benih ber-sertifikat, dan pemeliharaan tanaman dilakukan oleh ketua dan anggota kelompok tani di bawah arahan tim Pengabdian Masyarakat dan mahasiswa KKNM seperti yang telah dijelaskan pada penyuluhan. Dokumentasi kegiatan dapat dilihat pada Lampiran. Pelaksanaan kegiatan di Desa Cigadog dan Mandalagiri dapat dilihat pada Tabel 2.

Yang menjadi faktor pendorong dalam kegiatan ini adalah:

1) keingintahuan dari para peserta yang cukup tinggi terhadap materi-materi penyuluhan yang diberikan;

2) antusiasme dan partisipasi aktif dari para peserta dalam mengikuti kegiatan;

3) sarana produksi pertanian (saprotan) yaitu: benih tanaman pangan dan sayuran, bahan-bahan untuk pupuk maupun pestisida organik yang mudah didapat dari local setempat;

4) adanya lahan untuk demplot yang representatif;

5) peranan Kepala desa dan mahasiswa KKNM yang sangat menunjang kegiatan ini; dan

6) ruang pertemuan yang cukup memadai untuk diadakannya penyuluhan menggunakan multimedia berupa laptop dan infokus. 
Yang menjadi faktor penghambat dalam kegiatan ini adalah:

1) padatnya kegiatan rutin petani di Desa Cigadog dan Mandalagiri, sehingga kurang tersedianya waktu untuk kegiatan tambahan di luar kegiatan rutin sehingga pelaksanaan mundur dari jadwal yang sudah ditentukan;

2) luasan lahan petani pemilik rata-rata sempit yaitu berkisar antara 0,1 sampai 0,5 ha sehingga dirasakan kurang efisien dalam penggunaan sarana produksi; dan

3) kurang maksimalnya peranan tenaga penyuluh karena areal tugasnya yang terlalu luas.

Tabel 2. Pelaksanaan Kegiatan di Desa Cigadog dan Mandalagiri Kecamatan Leuwisari, Kabupaten Tasikmalaya.

\begin{tabular}{|c|c|c|c|}
\hline No. & $\begin{array}{c}\text { Jenis } \\
\text { Kegiatan }\end{array}$ & Uraian & $\begin{array}{c}\text { Tanggal } \\
\text { Pelaksanaan }\end{array}$ \\
\hline 1 & $\begin{array}{l}\text { Survey dan } \\
\text { pendataan } \\
\text { peserta } \\
\text { kegiatan }\end{array}$ & $\begin{array}{l}\text { Survey potensi } \\
\text { desa untuk } \\
\text { pengembangan } \\
\text { tanaman } \\
\text { pangan dan } \\
\text { sayuran dengan } \\
\text { penggunaan benih } \\
\text { bersertifikat }\end{array}$ & 10 Juni 2014 \\
\hline 2 & & $\begin{array}{l}\text { Pendataan peserta } \\
\text { yang potensial } \\
\text { ikut kegiatan } \\
\text { Pembuatan } \\
\text { undangan kegiatan } \\
\text { penyuluhan }\end{array}$ & 2 Juli 2014 \\
\hline 3 & & $\begin{array}{l}\text { Persiapan tempat } \\
\text { dan bahan-bahan } \\
\text { penunjang } \\
\text { untuk kegiatan } \\
\text { penyuluhan }\end{array}$ & 14 Juli 2014 \\
\hline 4 & Penyuluhan & $\begin{array}{l}\text { Penyuluhan } \\
\text { tentang Low } \\
\text { External Input } \\
\text { Sustainable } \\
\text { Agriculture } \\
\text { (LEISA) }\end{array}$ & 15 Juli 2014 \\
\hline 5 & & $\begin{array}{l}\text { Penyuluhan } \\
\text { Pengembangan } \\
\text { Lahan Kering } \\
\text { dengan Sistem } \\
\text { LEISA }\end{array}$ & 15 Juli 2014 \\
\hline 6 & Demplot & $\begin{array}{l}\text { Demplot dibuat } \\
\text { oleh masyarakat } \\
\text { pada lahan milik } \\
\text { masyarakat di } \\
\text { Desa Cigadog dan } \\
\text { Mndalagiri }\end{array}$ & $16 \underset{2014}{16}$ dan 17 Juli \\
\hline 7 & $\begin{array}{l}\text { Evaluasi } \\
\text { demplot }\end{array}$ & $\begin{array}{l}\text { Evaluasi } \\
\text { dilakukan } \\
\text { terhadap demplot } \\
\text { penggunaan benih } \\
\text { bersertifikat }\end{array}$ & 12 Agustus 2014 \\
\hline 8 & $\begin{array}{l}\text { Pemeliharaan } \\
\text { demplot }\end{array}$ & $\begin{array}{l}\text { Pemeliharaan } \\
\text { tanaman pada } \\
\text { demplot yang } \\
\text { dilakukan oleh } \\
\text { masyarakat }\end{array}$ & $\begin{array}{l}\text { 16 Juli sampai } \\
\text { Oktober } 2014\end{array}$ \\
\hline 9 & Pembinaan & $\begin{array}{l}\text { Pembinaan } \\
\text { dilakukan dengan } \\
\text { monitoring } \\
\text { melalui kontak } \\
\text { telepon }\end{array}$ & Juli-Oktober 2014 \\
\hline
\end{tabular}

Keberlanjutan program dilakukan dengan terus mengadakan pembinaan dan pendampingan dalam hal sistem LEISA untuk meningkatkan pertanian di lahan kering. Dari hasil penyuluhan ini terdapat peningkatan pengetahuan dan wawasan petani sebelum dan sesudah kegiatan penyuluhan yang dapat diukur dari pertanyaan-pertanyaan/kuosioner sederhana yang dilakukan sebelum dan sesudah kegiatan penyuluhan seperti terlihat pada Tabel 3 .

Tabel 3. Indikator Pelaksanaan Kegiatan di Desa Cigadog dan Mandalagiri

\begin{tabular}{|c|c|c|c|}
\hline No. & Indikator & $\begin{array}{c}\text { Base Line } \\
\text { (Sebelum } \\
\text { Kegiatan) }(\%)\end{array}$ & $\begin{array}{c}\text { Pencapaian } \\
\text { Setelah Kegiatan } \\
(\%)\end{array}$ \\
\hline 1 & $\begin{array}{l}\text { Pengetahuan } \\
\text { petani tentang } \\
\text { pertanian } \\
\text { berkelanjutan }\end{array}$ & 25 & 80 \\
\hline 2 & $\begin{array}{l}\text { Pengetahuan } \\
\text { petani tentang } \\
\text { teknik budidaya } \\
\text { tanaman di lahan } \\
\text { kering }\end{array}$ & 60 & 90 \\
\hline 3 & $\begin{array}{l}\text { Pengetahuan dan } \\
\text { keterampilan } \\
\text { petani dalam } \\
\text { sistem LEISA }\end{array}$ & 20 & 75 \\
\hline 4 & $\begin{array}{l}\text { Pengetahuan dan } \\
\text { keterampilan } \\
\text { petani dalam } \\
\text { pembuatan pupuk } \\
\text { organik }\end{array}$ & 50 & 90 \\
\hline 5 & $\begin{array}{l}\text { Pengetahuan dan } \\
\text { keterampilan } \\
\text { petani dalam } \\
\text { pembuatan } \\
\text { pestisida organik }\end{array}$ & 20 & 80 \\
\hline 6 & $\begin{array}{l}\text { Keinginan } \\
\text { petani untuk } \\
\text { menggunakan } \\
\text { sistem LEISA } \\
\text { untuk pertanian } \\
\text { lahan kering }\end{array}$ & 10 & 60 \\
\hline
\end{tabular}

Dari hasil kegiatan penyuluhan dan demonstrasi sistem LEISA untuk meningkatkan pertanian di lahan kering, dapat disimpulkan sebagai berikut.

1) Sumber daya alam maupun sumber daya manusia di Desa Cigadog dan Mandalagiri Kecamatan Leuwiari Kabupaten Tasikmalaya memiliki potensi untuk pengembangan produksi tanaman di lahan kering melalui sistem LEISA, karena lahan yang masih luas dengan tingkat kesuburan yang cukup serta sebagian besar penduduk bermatapencaharian sebagai petani.

2) Secara umum, program penyuluhan dianggap berhasil karena adanya peningkatan sasaran antara strategis dari tidak tahu menjadi tahu dan terampil, beberapa sasaran antara strategis yang diberi penyuluhan menyatakan ketertarikan untuk menggunakan benih bersertifkat, pupuk dan pestisida organik dengan memnfaatkan potensi lokal, dan menggunakan pola tanam yang lebih efgektif untuk meningkatkan produksi tanaman yang mereka usahakan khususnya di lahan kering, dan akan menularkan ilmunya ke petani lainnya.

3) Salah satu masalah yang masih menjadi kendala dalam mendukung untuk merealisasikan potensi tersebut adalah terbatasnya petugas penyuluh pertanian yang harus melayani daerah yang cukup luas sehingga pembinaan terhadap petani kurang maksimal. 


\section{Saran}

Dari hasil kegiatan ini disarankan hal berikut.

1) Adanya tindak lanjut dari masyarakat Desa Cigadog dan Mandalagiri untuk terus memanfaatkan sistem LEISA untuk pertanian yang berkelanjutan
2) Perlunya penambahan petugas (penyuluh pertanian) yang terus membimbing dan memfasilitasi petani untuk terus menerapkan pertanian berkelanjutan. 